\title{
Fecal Microbiota and Diet of Children with Chronic Constipation
}

\author{
Joyce Gomes de Moraes, ${ }^{1}$ Maria Eugênia Farias de Almeida Motta, ${ }^{2}$ \\ Monique Ferraz de Sá Beltrão, ${ }^{3}$ Taciana Lima Salviano, ${ }^{3}$ and Giselia Alves Pontes da Silva ${ }^{2}$ \\ ${ }^{1}$ Federal University of Pernambuco, Avenida Professor Moraes Rego 1235, University City, 50670-901 Recife, PE, Brazil \\ ${ }^{2}$ Mother-Child Department, Federal University of Pernambuco, Avenida Professor Moraes Rego 1235, University City, \\ 50670-901 Recife, PE, Brazil \\ ${ }^{3}$ Department of Biotechnology, Laboratory of Immunopathology Keizo Asami (LIKA), Avenida Professor Moraes Rego 1235, \\ University City, 50670-901 Recife, PE, Brazil
}

Correspondence should be addressed to Joyce Gomes de Moraes; tenjoyce@hotmail.com

Received 29 November 2015; Accepted 18 May 2016

Academic Editor: Samuel Menahem

Copyright (C) 2016 Joyce Gomes de Moraes et al. This is an open access article distributed under the Creative Commons Attribution License, which permits unrestricted use, distribution, and reproduction in any medium, provided the original work is properly cited.

\begin{abstract}
Many factors explain dysbiosis in chronic constipation (CC), such as a low-fiber diet. The objective of this study was to compare the fecal microbiota of constipated and nonconstipated children and their intake frequencies of food. Methods. This observational study included 79 children (M/F 43/36) aged six to 36 months divided into two groups: cases (39 constipated children) and controls (40 nonconstipated children). We used a structured form to collect demographic variables, conducted anthropometric assessment, and collected food intake frequency data. The fecal microbiota of the stool samples was analyzed by real-time polymerase chain reaction (PCR) using the fluorophore SYBR ${ }^{\circledR}$ Green. Results. Constipated children had a smaller concentration of Lactobacillus per milligram of stool ( $p=0.015$ ) than nonconstipated children, but the concentration of Bifidobacterium per milligram of stool $(p=0.323)$ and the intake of fruits, vegetables $(p=0.563)$, and junk food $(p=0.093)$ of the two groups did not differ. Constipated children consumed more dairy products $(0.45 \pm 0.8 ; p>0.001)$, were more frequently delivered via caesarean section $(69.2 \%)$, were weaned earlier (median: $120 ; 60 \mathrm{Q}_{1}-240 \mathrm{Q}_{3}$ ), and had a family history of constipation $(71.8 \%)$. Conclusions. Children with CC have a smaller concentration of Lactobacillus in their stools and consume more dairy products.
\end{abstract}

\section{Introduction}

Chronic constipation (CC) is frequent in children and corresponds to approximately $25 \%$ of visits to pediatric gastroenterology offices [1]. Most CC cases in small children can be explained by functional changes [2] secondary to a low-fiber diet [3] and early weaning [4].

Studies suggest that chronically constipated children have different intestinal microbiota $[5,6]$ and that factors such as caesarean birth, early weaning, and low-fiber diets hinder intestinal colonization by healthy microorganisms $[7,8]$.

Diet is critical among factors capable of modulating the intestinal microbiota [9-11] because saccharolytic bacteria, such as those from the genera Bifidobacterium and
Lactobacillus, ferment fibers into short-chain fatty acids (SCFA), reducing intestinal $\mathrm{pH}$ and consequently increasing intestinal motility [12-15].

It is possible that there is altered intestinal microbiota in patients with Functional Gastrointestinal Diseases repercussions on intestinal motility [16-18]. Based on this hypothesis, researchers suggest a beneficial effect of the use of probiotics in the management of constipation, especially Lactobacillus and Bifidobacterium [18-20] what motivated us to conduct this study and we decided to compare the amount of bacteria from the genera Lactobacillus and Bifidobacterium in the fecal microbiota of constipated and nonconstipated children using SYBR Green analysis and investigate the children's intake of fruits, vegetables, junk food, and dairy products. 
TABLE 1: Primers of groups in real-time polymerase chain reaction.

\begin{tabular}{lcc}
\hline Group or species & Oligonucleotide sequence $\left(5^{\prime}-3^{\prime}\right)$ & Verification media \\
\hline Eubacteria (total bacteria) & UniF340: ACTCCTACGGGAGGCAGCAGT & 11 strains of Eubacteria \\
& UniR514: ATTACCGCGGCTGCTGGC & \\
\hline & gLactoF: TGGAAACAGRTGCTAATACCG & \\
Lactobacillus spp. & gLactoR: GTCCATTGTGGAAGATTCCC & 21 strains of Lactobacillus \\
& LacAcR: GCGGAAACCTCCCAACA & \\
\hline & gBifidF: CTCCTGGAAACGGGTGG & [25] strains of Bifidobacterium \\
Bifidobacterium spp. & gBifidR: GGTGTTCTTCCCGATATCTACA & [26] \\
\hline
\end{tabular}

\section{Methods}

This observational study was conducted from March to December 2013, in a primary care unit, with 79 children from low-income families. The children were divided into two groups, recruited in consecutive order, and diagnosed according to the Rome III Diagnostic Criteria [21]: cases, 39 children with CC aged six months to less than three years, and controls, 40 children without CC matched for age.

The cases were children who had at least two of the following parameters for at least one month: two or fewer defecations a week; at least one episode of incontinence a week; history of excessive stool retention; at least one episode of hard or painful bowel movement a week; and history of large diameter stools that may obstruct the toilet [22]. The controls did not have a history of constipation. The control group consisted of healthy children assisted in the primary care unit, who had no previous history of constipation and had none of the parameters used in Roma III Criteria.

All children with a diagnosis of genetic syndromes, delayed neuropsychomotor development, chronic encephalopathy, celiac disease, or Hirschsprung's disease; evidence of constipation secondary to anatomic (anal stenosis) or functional (intestinal pseudo-obstruction) abnormalities; and evidence of constipation secondary to cow milk allergy were excluded. The mothers were informed orally of the study objectives, operationalization, and ethical aspects and signed an informed consent form before their children were enrolled in the study.

This study was approved by the Research Ethics Committee of the Federal University of Pernambuco under protocol number 165,098, on December 05, 2012, and followed all the rules established by Resolution 196 of the National Council of Health.

The structured form collected the following data: sex, age, history of prematurity, family history of constipation, time of weaning, and nutritional status. A food frequency questionnaire (FFQ) with 96 foods collected the children's dietary data.

The children's nutritional status was classified according to their body mass index- (BMI-) for-age $z$-scores using the curve provided by the World Health Organization (WHO) for children aged 0 to 5 years. The following cut-off points were used: extreme underweight when $z$-score $<-3$; underweight when $-3 \leq z$-score $<-2$; normal weight when $-2 \leq z$-score $\leq+1$; risk of overweight when $+1<z$-score $\leq+2$; overweight when $+2<z$-score $\leq+3$; and obesity when $z$-score $>+3$ [27]. BMI-for-age was calculated by the software WHO Anthro Plus of WHO.

After nutritional status assessment, a stool sample was collected from each child and placed in a sterile polypropylene container. The stool samples were transported in icefilled coolers and stored in a freezer at $-18^{\circ} \mathrm{C}$ until molecular analysis.

The FFQ was assessed as recommended by de Fornés et al. [28] with adaptations, where the general intake frequency is converted into scores. Six food groups were constituted: grains, tubers, and roots (group I); beans and high-protein plant foods (group II); fruits and vegetables (group III); milk and dairy products (group IV); meats and eggs (group V); and junk food (group VI).

The answers (never, daily, weekly, monthly, and annually) were transformed into monthly intake frequencies. Foods were consumed daily and never received maximum $(S=1)$ and minimum $(S=0)$ scores, respectively. Intermediate scores were given by the formula $S=n / 30$, where $n$ is the number of days in a month that the child consumed a given food $[28,29]$.

The Laboratory of Immunopathology Keizo Asami of the Federal University of Pernambuco (LIKA/UFPE) analyzed the stool samples by real-time polymerase chain reaction (PCR) using the fluorophore SYBR Green. The commercial kit QIAamp DNA Stool ${ }^{\mathrm{TM}}$ (QIAGEN, Venlo, Netherlands) was used for extracting DNA from the samples as instructed by the manufacturer. The amplification reactions used reagents standardized for real-time PCR (Universal PCR Master Mix) and a set of primers specific for the genera Lactobacillus and Bifidobacterium and total bacteria. The primers were acquired from studies on fecal microbiota analysis by real-time PCR (SYBR Green) (Table 1).

The statistical analyses were performed by the software Statistical Package for Social Sciences (SPSS) for Windows version 13.0 (SPSS Inc., Chicago, IL, USA). The numeric variables were represented by measures of central tendency and dispersion. The chi-square test and Fisher's exact test measured associations between the categorical variables. The Kolmogorov-Smirnov test determined whether the quantitative variables had a normal distribution. Student's $t$-test 
TABLE 2: General characteristics of the sample.

\begin{tabular}{|c|c|c|c|c|}
\hline Variables & $\begin{array}{l}\text { Constipated children } \\
\text { (39) } n(\%)\end{array}$ & $\begin{array}{c}\text { Nonconstipated } \\
\text { children (40) } n(\%)\end{array}$ & $\begin{array}{l}\text { Total } \\
n(\%)\end{array}$ & $p$ value \\
\hline $\operatorname{Sex} n(\%)$ & & & & $0.305^{\bullet}$ \\
\hline Female & $15(38.5)$ & $21(52.5)$ & $36(45.6)$ & \\
\hline Male & $24(61.5)$ & $19(47.5)$ & $43(54.4)$ & \\
\hline Age (months) $)^{\diamond s}$ & $16.7 \pm 8.3$ & $15.6 \pm 6.7$ & & $0.532^{*}$ \\
\hline Nutritional status $n(\%)$ & & & & $0.597^{\dagger}$ \\
\hline Underweight/normal & $31(79.5)$ & $28(71.8)$ & $59(75.6)$ & \\
\hline Overweight/obese & $8(20.5)$ & $11(28.2)$ & $19(24.4)$ & \\
\hline Delivery $n(\%)$ & & & & $0.084^{\prime \prime}$ \\
\hline Vaginal & $12(30.8)$ & $21(52.5)$ & $33(41.8)$ & \\
\hline Caesarean & $27(69.2)$ & $19(47.5)$ & $46(58.2)$ & \\
\hline Premature n (\%) & & & & $1.00^{\dagger}$ \\
\hline Yes & $3(7.7)$ & $3(7.5)$ & $6(7.6)$ & \\
\hline No & $36(92.3)$ & $37(92.5)$ & $73(92.4)$ & \\
\hline Family history of constipation $n$ (\%) & & & & $0.016^{\circ}$ \\
\hline Yes & $28(71.8)$ & $17(42.5)$ & $45(57)$ & \\
\hline No & $11(28.2)$ & $23(57.5)$ & $34(43)$ & \\
\hline Breastfeeding duration (days) ${ }^{*}$ & $120(60 ; 240)$ & $270(180 ; 360)$ & & $0.006^{*}$ \\
\hline
\end{tabular}

TABLE 3: Median and interquartile ranges of the food intake frequency scores of constipated and nonconstipated children.

\begin{tabular}{|c|c|c|c|}
\hline Variables & $\begin{array}{l}\text { Constipated } \\
\text { children (39) }\end{array}$ & $\begin{array}{c}\text { Nonconstipated } \\
\text { children (40) }\end{array}$ & $p$ value \\
\hline Group 1 (grains, tubers, and roots) ${ }^{*}$ & $0.24(0.17 ; 0.30)$ & $0.22(0.15 ; 0.28)$ & 0.220 \\
\hline Group 2 (beans and other high-protein plant foods) ${ }^{*}$ & $0.20(0.08 ; 0.20)$ & $0.20(0.08 ; 0.20)$ & 0.858 \\
\hline Group 3 (fruits and vegetables) ${ }^{*}$ & $0.21(0.12 ; 0.31)$ & $0.20(0.12 ; 0.28)$ & 0.563 \\
\hline Group 4 (milk and dairy products) $)^{\S}$ & $0.45 \pm 0.18$ & $0.27 \pm 0.17$ & $<0.001$ \\
\hline Group 6 (junk food) ${ }^{\S}$ & $0.15 \pm 0.11$ & $0.11 \pm 0.09$ & 0.093 \\
\hline
\end{tabular}

${ }^{*}$ Median and percentiles (25th and 75th), Mann-Whitney test.

${ }^{\S}$ Mean \pm standard deviation.

and the Mann-Whitney test compared the variables with and without normal distribution, respectively, especially variables related to the microbiota. Statistical analysis of microbiotarelated data was performed by the software Graphpad Prism using the same criteria cited above. Since food intake frequencies are ordinal measurements, they were expressed as medians and interquartile ranges. The significance level was set at $5 \%(p \leq 0.05)$.

\section{Results}

A total of 79 children participated in the study, 39 cases and 40 controls. Thirty case and 29 control stools were analyzed. Total bacteria could not be amplified in one case. The other study variables of the children did not differ regardless of fecal microbiota analysis.

Table 2 shows the general characteristics of the sample.

Most constipated children had a positive family history of constipation (71.8\%; $p=0.016$ ), a higher frequency of cesarean delivery $(69.2 \% ; p=0.084)$, and a shorter duration of breastfeeding (median: $120 ; 60 \mathrm{Q}_{1}-240 \mathrm{Q}_{3} ; p=0.006$ ).

The groups had similar intakes of fruits and vegetables ( $p=0.563)$. However, constipated children consumed more dairy products $(p<0.001)$ and junk food $(p=0.093)$ (Table 3), combined with a significantly smaller amount of Lactobacillus genus per milligram of stools $(p=0.022)$ when compared to children not constipated ( $p=0.015)$ (Figure 3 ).

The two groups had similar total bacteria counts per milligram of stool ( $p=0.325$ ) (Figure 1 ) and similar counts of the genus Bifidobacterium per milligram of stool $(p=0.323)$ (Figure 2).

\section{Discussion}

Constipated children had a smaller number of Lactobacillus per milligram of feces and the same number of Bifidobacterium as nonconstipated children, which may be characterized as dysbiosis [30]. Conceptually, both qualitative and 


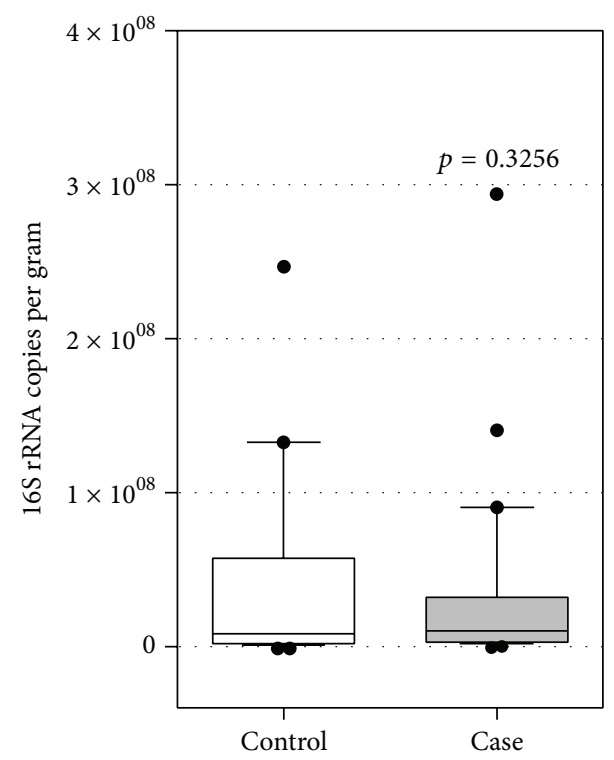

FIGURE 1: Total bacterial 16S rRNA gene copies detected per gram of healthy (control) and constipated (case) children stools ( $n=29$ for each population). Box plots show the 10th to 90th percentile range of the data within the box, with outliers indicated as dots. $p$ value with $95 \%$ CI was calculated by $t$-test.

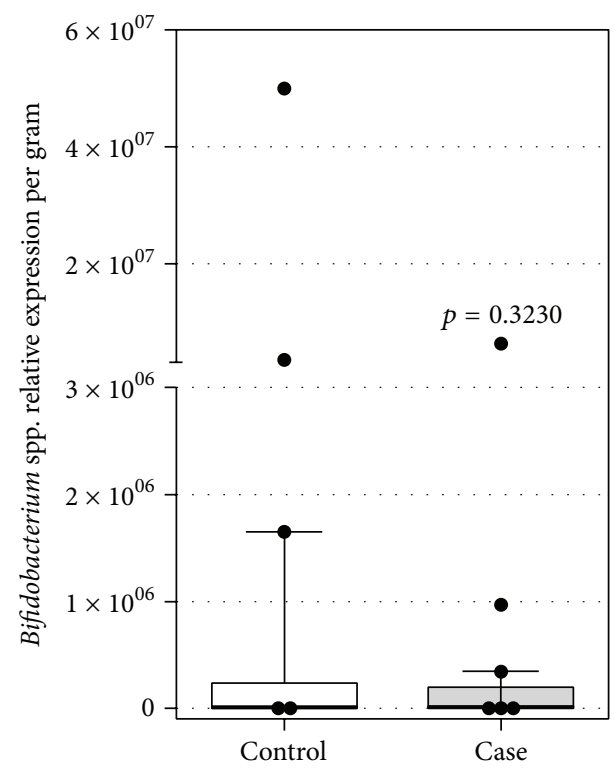

FIGURE 2: Relative expression of Bifidobacterium spp. analyzed by RT-qPCR in stools of healthy (control) and constipated (case) children ( $n=29$ for each population) (Bifidobacterium genus per $\mathrm{mg}$ of stool of the two study groups).

quantitative changes in intestinal microbiota as bacterial overgrowth are classified as dysbiosis [31]. Constipated children consumed dairy products and sweets more frequently.

Diet modulates the intestinal microbiota significantly [11, 32, 33]. Some nutrients in excess, such as simple sugars, proteins $[34,35]$, and some types of lipids, are capable of reducing bacterial genera that promote intestinal motility

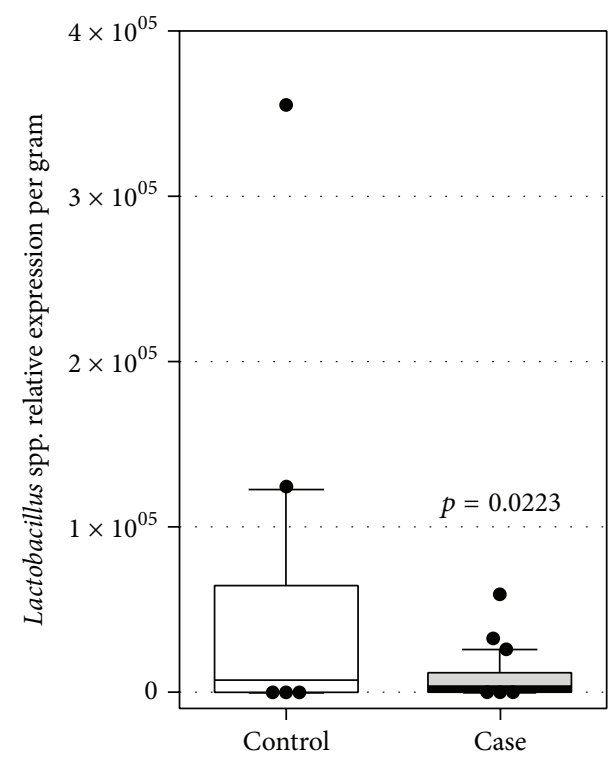

FIGURE 3: Relative expression of Lactobacillus spp. analyzed by RTqPCR in stools of healthy (control) and constipated (case) children ( $n=29-30$ for each population).

$[10,35]$. On the other hand, it is described that some fibers improve intestinal motility by stimulating bacterial genera with fermentative and saccharolytic activities [11, 15, 35-37].

High intakes of simple sugars, fatty acids, and proteins change the composition of the intestinal microbiota $[9,38$, 39] and have been associated with intestinal constipation in children. Crowley et al. found that cow milk protein was positively associated with intestinal constipation in children aged three to twelve years, but the mechanisms had not been fully elucidated [40]. Kocaay et al. verified a positive association between intestinal constipation and cow milk intake in excess of $250 \mathrm{~mL}$ per day, which the authors believed was caused by the saponification of fatty acids with calcium [41]. Other authors consider that excess protein intake changes the intestinal microbiota $[9,38,39]$.

It is noteworthy that constipated children consumed sweets more frequently and dairy products significantly more frequently. It is possible that the high intake frequency of these foods by constipated children led them to consume fewer foods with higher fiber content, such as fruits and vegetables, for example.

On the other hand, foods with high simple sugar, fatty acid, and protein contents, such as dairy products and sweets, are associated with fewer Lactobacillus $[9,10]$ genera in children's intestinal microbiota because they promote the growth of other bacterial genera [10]. Hence, these mechanisms may justify the low Lactobacillus count per milligram of feces in samples of children with high intake of sweets and dairy products.

In agreement with the study results, other observational studies did not detect a smaller number of bacteria from the genera Bifidobacterium in the fecal microbiota of constipated children and children with low fiber intake [6, 42]. Using the table of the Association of Official Analytical Chemists 
to determine dietary fiber intake, Aguirre et al. did not find a significant difference in the fiber intake of constipated and nonconstipated children [42].

However, studies that related fiber intake to intestinal constipation are controversial, possibly because of the different methods and tables used for determining fiber intake $[43,44]$. Based on the fiber intake recommended by the Academy of Pediatrics, Ip et al. found that constipated children consume less fiber than nonconstipated children [45]. The methods used by Aguirre et al. and Ip et al. to calculate fiber intake differed from the method used by the present study $[42,45]$.

De Filippo et al. reported that children with high-fiber diets have more bifidobacteria in their intestinal microbiota than children with low-fiber diets [11]. Bernal et al. obtained similar results [46].

Therefore, fruit and vegetable intake seems to increase the number of Bifidobacterium in fecal microbiota [47], and children who consume fewer fruits and vegetables have more constipation than children who consume adequate amounts of these foods [48-50]. The number of Bifidobacterium by milligram of feces was not associated with fruit and vegetable intake frequency in either study group.

Conceptually, the role played by fibers on intestinal motility is associated with its action on the intestinal microbiota. People are incapable of hydrolyzing this nutrient, so the intestinal microbiota synthesizes hydrolases that break down fibers. As the intestinal microbiota ferments fiber, it produces short-chain fatty acids (SCFA), which reduce intestinal $\mathrm{pH}$. Low intestinal $\mathrm{pH}$ reduces intestinal transit time $[51,52]$ and stimulates smooth muscles, actions that promote peristalsis. Low intestinal $\mathrm{pH}$ also promotes the growth of beneficial intestinal microbiota $[10,53]$, especially bacteria from the genera Bifidobacterium $[10,15]$ and Lactobacillus $[13,14]$, and inhibits the growth of pathogens $[10,35,37,54]$.

Bacteria from the genera Bifidobacterium and Lactobacillus are important constituents of children's microbiota [55, 56]. Constipation during childhood promotes qualitative and quantitative changes in the intestinal microbiota, especially with respect to these genera [56-58], which influences peristalsis. However, the exact mechanisms have not yet been fully elucidated [59-61].

Most study children with constipation had a family history of constipation along with a higher frequency of caesarian delivery and shorter breastfeeding duration. This fact may be justified by shared food habits and intestinal microbiota between family members [62]. This frequency is high and above the frequency found in other European studies, which found frequencies ranging from $13 \%$ to roughly $54 \%$ [41, 45, 63-65].

However the study frequency was very close to that found by a Brazilian study, which attributed the high frequency of constipation among family members $(81.6 \%)$ to their common food habits [62]. This difference between studies may stem from the method used, since family members with constipation were presently identified by ROMA III while other studies used a questionnaire or retrospective assessment of the medical records.
Vaginal delivery and breastfeeding are thought to be key players in the colonization and succession of healthy microorganisms in children's digestive tract [41, 42, 66-68]. In agreement with our findings, Mitsou et al. found that changes in children's intestinal microbiota are associated with a higher frequency of caesarian delivery and characterized by a smaller number of Lactobacillus in their intestinal microbiota [67].

Breast milk contains not only Lactobacillus in its composition [69-71] but also prebiotics that favor their proliferation in children's intestines [72-74]. The mother's intestinal microbiota influences the microbiota present in breast milk. Breast milk bacteria differ from skin bacteria. During pregnancy, high intestinal permeability allows the translocation of intestinal bacteria to Peyer's patches and lamina propria, and mononuclear cells then transfer them to the mammary glands $[75,76]$.

During vaginal delivery, the mother's microbiota is transferred to the child by a process called verticalization. In other words, the child is inoculated orally by the mother's vaginal and intestinal microbiota as the child passes through the birth canal. Thus, children born by vaginal delivery have more diverse intestinal microbiota, which is very similar to the mother's intestinal microbiota. On the other hand, children born by caesarian delivery are colonized later by the bacteria present in the environment [30, 76-80].

Studies have used cultures to analyze fecal microbiota [6, 58 ] even though only a small percentage of the species that compose fecal microbiota can be analyzed by this technique. The present study used molecular techniques to analyze fecal microbiota.

The present results corroborate those of Zoppi et al., who used cultures to analyze the intestinal microbiota of children and also found that constipated children have a smaller number of Lactobacillus and the same number of Bifidobacterium as nonconstipated children, which has been characterized by the authors as dysbiosis [6].

Despite the scarcity of studies on the fecal microbiota of constipated individuals, there is a reasonable number of studies on the use of probiotics to revert this condition [1820,81-85]. Intervention studies have shown that the use of probiotics in constipated children improves the symptoms $[20,85]$, suggesting that their use is capable of modulating the fecal microbiota, which is associated with an improvement in childhood constipation $[86,87]$. It may be indirectly inferred that changes in the intestinal microbiota are a major factor in the pathophysiology of constipation in children.

\section{Conclusion}

Thus, our results showed that constipated children had a positive maternal history for constipation associated with a higher rate of cesarean delivery, a shorter time of breastfeeding, and increased consumption of junk foods and dairy products combined with dysbiosis. No empirical basis for inferring the dysbiosis is causative factor or a result of constipation, which in its complex and multifactorial character needs to have these and more other factors involved most be studied. 


\section{Competing Interests}

The authors declare no conflict of interests.

\section{Authors' Contributions}

Joyce Gomes de Moraes conceived and designed the study, conducted data collection, analyzed the data, and drafted the paper; Maria Eugênia Farias de Almeida Motta conceived and designed the study; Monique Ferraz de Sá Beltrão and Taciana Lima Salviano analyzed and interpreted the data, provided advice, and critically revised the paper; Giselia Alves Pontes da Silva conceived and designed the study, interpreted the data, provided advice, and critically revised the paper. All authors approved the final version of the paper.

\section{Acknowledgments}

The authors thank José Luiz de Lima Filho, Director of LIKA, for letting them use LIKA facilities for fecal microbiota analysis and $\mathrm{CNPq}$ for the scholarship and the support of Giselia A. P. da Silva.

\section{References}

[1] L. Ambartsumyan and L. Rodriguez, "Gastrointestinal motility disorders in children," Gastroenterology and Hepatology, vol. 10, no. 1, pp. 16-26, 2014.

[2] I. Xinias and A. Mavroudi, "Constipation in childhood. An update on evaluation and management," Hippokratia, vol. 19, no. 1, pp. 11-19, 2015.

[3] M. M. Tabbers, N. Boluyt, M. Y. Berger, and M. A. Benninga, "Nonpharmacologic treatments for childhood constipation: systematic review," Pediatrics, vol. 128, no. 4, pp. 753-761, 2011.

[4] A. D. Camurdan, U. Beyazova, S. Ozkan, and V. T. Tunc, "Defecation patterns of the infants mainly breastfed from birth till the 12th month: prospective cohort study," The Turkish Journal of Gastroenterology, vol. 25, supplement 1, pp. 1-5, 2014.

[5] L. Zhu, W. Liu, R. Alkhouri et al., "Structural changes in the gut microbiome of constipated patients," Physiological Genomics, vol. 46, no. 18, pp. 679-686, 2014.

[6] G. Zoppi, M. Cinquetti, A. Luciano, A. Benini, A. Muner, and E. B. Minelli, "The intestinal ecosystem in chronic functional constipation," Acta Paediatrica, International Journal of Paediatrics, vol. 87, no. 8, pp. 836-841, 1998.

[7] P. M. Munyaka, E. Khafipour, and J. Ghia, "External influence of early childhood establishment of gut microbiota and subsequent health implications," Frontiers in Pediatrics, vol. 2, article 109, pp. 1-9, 2014.

[8] M.-C. Arrieta, L. T. Stiemsma, N. Amenyogbe, E. Brown, and B. Finlay, "The intestinal microbiome in early life: health and disease," Frontiers in Immunology, vol. 5, article 427, 2014.

[9] S. N. Heinritz, E. Weiss, M. Eklund et al., "Intestinal microbiota and microbial metabolites are changed in a pig model fed a high-fat/low-fiber or a low-fat/high-fiber diet," PLOS ONE, vol. 11, no. 4, Article ID e0154329, 2016.

[10] K. Brown, D. DeCoffe, E. Molcan, and D. L. Gibson, "Dietinduced dysbiosis of the intestinal microbiota and the effects on immunity and disease," Nutrients, vol. 4, no. 8, pp. 1095-1119, 2012.
[11] C. De Filippo, D. Cavalieri, M. Di Paola et al., "Impact of diet in shaping gut microbiota revealed by a comparative study in children from Europe and rural Africa," Proceedings of the National Academy of Sciences of the United States of America, vol. 107, no. 33, pp. 14691-14696, 2010.

[12] T.-H. Jung, W.-M. Jeon, and K.-S. Han, "In vitro effects of dietary inulin on human fecal microbiota and butyrate production," Journal of Microbiology and Biotechnology, vol. 25, no. 9, pp. 1555-1558, 2015.

[13] A. L. Kau, P. P. Ahern, N. W. Griffin, A. L. Goodman, and J. I. Gordon, "Human nutrition, the gut microbiome and the immune system," Nature, vol. 474, no. 7351, pp. 327-336, 2011.

[14] Q. Shen, L. Zhao, and K. M. Tuohy, "High-level dietary fibre up-regulates colonic fermentation and relative abundance of saccharolytic bacteria within the human faecal microbiota in vitro," European Journal of Nutrition, vol. 51, no. 6, pp. 693-705, 2012.

[15] K. Pokusaeva, G. F. Fitzgerald, and D. Van Sinderen, "Carbohydrate metabolism in Bifidobacteria," Genes and Nutrition, vol. 6, no. 3, pp. 285-306, 2011.

[16] E. M. Quigley, "Probiotics in irritable bowel syndrome the science and the evidence," Journal of Clinical Gastroenterology, vol. 49, supplement 1, pp. S60-S64, 2015.

[17] Y. Ringel and T. Ringel-Kulka, "The intestinal microbiota and irritable bowel syndrome," Journal of Clinical Gastroenterology, vol. 49, pp. S56-S59, 2015.

[18] K. Hod and Y. Ringel, "Probiotics in functional bowel disorders," Best Practice \& Research Clinical Gastroenterology, vol. 30, no. 1, pp. 89-97, 2016.

[19] Y. Vandenplas, G. Huys, and G. Daube, "Probiotics: an update," Jornal de Pediatria, vol. 91, no. 1, pp. 6-21, 2015.

[20] J. J. Korterink, L. Ockeloen, M. A. Benninga, M. M. Tabbers, M. Hilbink, and J. M. Deckers-Kocken, "Probiotics for childhood functional gastrointestinal disorders: a systematic review and meta-analysis," Acta Paediatrica, vol. 103, no. 4, pp. 365-372, 2014.

[21] D. Drossman, E. Corazziari, M. Delvaux et al., Rome III: The Functional Gastrointestinal Disorders, Degnon Associates, McLean, Va, USA, 2006.

[22] P. E. Hyman, P. J. Milla, M. A. Benninga, G. P. Davidson, D. F. Fleisher, and J. Taminiau, "Childhood functional gastrointestinal disorders: neonate/toddler," Gastroenterology, vol. 130, no. 5, pp. 1519-1526, 2006.

[23] R. I. Amann, B. J. Binder, R. J. Olson, S. W. Chisholm, R. Devereux, and D. A. Stahl, "Combination of $16 \mathrm{~S}$ rRNAtargeted oligonucleotide probes with flow cytometry for analyzing mixed microbial populations," Applied and Environmental Microbiology, vol. 56, no. 6, pp. 1919-1925, 1990.

[24] A. Croswell, E. Amir, P. Teggatz, M. Barman, and N. H. Salzman, "Prolonged impact of antibiotics on intestinal microbial ecology and susceptibility to enteric Salmonella infection," Infection and Immunity, vol. 77, no. 7, pp. 2741-2753, 2009.

[25] R. Byun, M. A. Nadkarni, K.-L. Chhour, F. E. Martin, N. A. Jacques, and N. Hunter, "Quantitative analysis of diverse Lactobacillus species present in advanced dental caries," Journal of Clinical Microbiology, vol. 42, no. 7, pp. 3128-3136, 2004.

[26] T. Matsuki, K. Watanabe, J. Fujimoto et al., "Quantitative PCR with $16 \mathrm{~S}$ rRNA-gene-targeted species-specific primers for analysis of human intestinal bifidobacteria," Applied and Environmental Microbiology, vol. 70, no. 1, pp. 167-173, 2004. 
[27] World Health Organization, WHO Child Growth Standards. Lengh/Height-for-Age, Weight-for-Age, Weight-for-Lengh, Weightfor-Height and Body Mass Index-for-Age. Methods and Development, WHO, Geneva, Switzerland, 2006.

[28] N. S. de Fornés, I. S. Martins, G. Velásquez-Meléndez, and M. D. R. Dias de Oliveira Latorre, "Food consumption scores and serum lipids levels in the population of São Paulo, Brazil," Revista de Saude Publica, vol. 36, no. 1, pp. 12-18, 2002.

[29] C. Pinho, P. Israel, C. D. Lira, F. Cristina, and S. Pastich, "Excesso de peso em adultos do Estado de Pernambuco, Brasil: magnitude e fatores associados," Cadernos de Saúde Pública, vol. 27, no. 12, pp. 2340-2350, 2011.

[30] P. D. Houghteling and W. A. Walker, "Why is initial bacterial colonization of the intestine important to infants' and children's health?" Journal of Pediatric Gastroenterology and Nutrition, vol. 60, no. 3, pp. 294-307, 2015.

[31] E. O. Petrof, E. C. Claud, G. B. Gloor, and E. AllenVercoe, "Microbial ecosystems therapeutics: a new paradigm in medicine?" Beneficial Microbes, vol. 4, no. 1, pp. 53-65, 2013.

[32] G. Trinchese, G. Cavaliere, R. B. Canani et al., "Human, donkey and cow milk differently affects energy efficiency and inflammatory state by modulating mitochondrial function and gut microbiota," Journal of Nutritional Biochemistry, vol. 26, no. 11, pp. 1136-1146, 2015.

[33] J. Siddharth, N. Holway, and S. J. Parkinson, "A western diet ecological module identified from the 'humanized' mouse microbiota predicts diet in adults and formula feeding in children," PLoS ONE, vol. 8, no. 12, Article ID e83689, 2013.

[34] E. Kim, D.-B. Kim, and J.-Y. Park, "Changes of mouse gut microbiota diversity and composition by modulating dietary protein and carbohydrate contents: a pilot study," Preventive Nutrition and Food Science, vol. 21, no. 1, pp. 57-61, 2016.

[35] H. L. Simpson and B. J. Campbell, "Review article: dietary fibremicrobiota interactions," Alimentary Pharmacology \& Therapeutics, vol. 42, no. 2, pp. 158-179, 2015.

[36] K. Aryana, F. Greenway, N. Dhurandhar et al., "A resistantstarch enriched yogurt: fermentability, sensory characteristics, and a pilot study in children," F1000Res, vol. 4, article 139, 2015.

[37] A. W. Walker, S. H. Duncan, E. Carol McWilliam Leitch, M. W. Child, and H. J. Flint, "pH and peptide supply can radically alter bacterial populations and short-chain fatty acid ratios within microbial communities from the human colon," Applied and Environmental Microbiology, vol. 71, no. 7, pp. 3692-3700, 2005.

[38] E. G. Zoetendal and W. M. de Vos, "Effect of diet on the intestinal microbiota and its activity," Current Opinion in Gastroenterology, vol. 30, no. 2, pp. 189-195, 2014.

[39] H. Brüssow, "Microbiota and healthy ageing: observational and nutritional intervention studies," Microbial Biotechnology, vol. 6, no. 4, pp. 326-334, 2013.

[40] E. T. Crowley, L. T. Williams, T. K. Roberts, R. H. Dunstan, and P. D. Jones, "Does milk cause constipation? A crossover dietary trial," Nutrients, vol. 5, no. 1, pp. 253-266, 2013.

[41] P. Kocaay, Ö. Egritas, and B. Dalgiç, "Normal defecation pattern, frequency of constipation and factors related to constipation in Turkish children 0-6 years old," Turkish Journal of Gastroenterology, vol. 22, no. 4, pp. 369-375, 2011.

[42] A. N. Aguirre, M. R. Vitolo, R. F. Puccini, and M. B. Morais, "Constipação em lactentes: influência do tipo de aleitamento e da ingestão de fibra alimentar," Jornal de Pediatria, vol. 78, no. 3, pp. 202-208, 2002.

[43] A. Torres and M. González, "Constipación crónica," Revista Chilena de Pediatría, vol. 86, no. 4, pp. 299-304, 2016.
[44] M. Vitolo, A. Aguirre, U. Fagundes-Neto, and M. de Morais, "Estimativa do consumo de fibra alimentar por crianças de acordo com diferentes tabelas de composição de alimentos," Archivos Latinoamericanos de Nutrición, vol. 48, no. 2, pp. 141145, 1998.

[45] K. S. Ip, W. T. K. Lee, J. S. H. Chan, and B. W. Y. Young, "A community-based study of the prevalence of constipation in young children and the role of dietary fibre," Hong Kong Medical Journal, vol. 11, no. 6, pp. 431-436, 2005.

[46] M. J. Bernal, M. J. Periago, R. Martínez et al., "Effects of infant cereals with different carbohydrate profiles on colonic function-randomised and double-blind clinical trial in infants aged between 6 and 12 months-pilot study," European Journal of Pediatrics, vol. 172, no. 11, pp. 1535-1542, 2013.

[47] E. Iwata, H. Hotta, and M. Goto, "The screening method of a bifidogenic dietary fiber extracted from inedible parts of vegetables," Journal of Nutritional Science and Vitaminology, vol. 55, no. 4, pp. 385-388, 2009.

[48] B. Sujatha, D. R. Velayutham, N. Deivamani, and S. Bavanandam, "Normal bowel pattern in children and dietary and other precipitating factors in functional constipation," Journal of Clinical and Diagnostic Research, vol. 9, no. 6, pp. SC12-SC15, 2015.

[49] S. M. Dehghani, H. Moravej, E. Rajaei, and H. Javaherizadeh, "Evaluation of familial aggregation, vegetable consumption, legumes consumption, and physical activity on functional constipation in families of children with functional constipation versus children without constipation," Przeglad Gastroenterologiczny, vol. 10, no. 2, pp. 89-93, 2015.

[50] A. Comas Vives and I. Polanco Allué, "Case-control study of risk factors associated with childhood constipation. The FREI study," Anales de Pediatria, vol. 62, no. 4, pp. 340-345, 2005.

[51] A. Pituch, J. Walkowiak, and A. Banaszkiewicz, "Butyric acid in functional constipation," Przeglad Gastroenterologiczny, vol. 8, no. 5, pp. 295-298, 2013.

[52] R. Holma, S.-M. Hongisto, M. Saxelin, and R. Korpela, "Constipation is relieved more by rye bread than wheat bread or laxatives without increased adverse gastrointestinal effects," Journal of Nutrition, vol. 140, no. 3, pp. 534-541, 2010.

[53] A. G. Flesch, A. K. Poziomyck, and D. D. Damin, "The therapeutic use of symbiotics," Arquivos Brasileiros de Cirurgia Digestiva, vol. 27, no. 3, pp. 206-209, 2014.

[54] M. Haarman and J. Knol, "Quantitative real-time PCR analysis of fecal Lactobacillus species in infants receiving a prebiotic infant formula," Applied and Environmental Microbiology, vol. 72, no. 4, pp. 2359-2365, 2006.

[55] A. Chmielewska and H. Szajewska, "Systematic review of randomised controlled trials: probiotics for functional constipation," World Journal of Gastroenterology, vol. 16, no. 1, pp. 69$75,2010$.

[56] K. Mikami, H. Takahashi, M. Kimura et al., "Influence of maternal bifidobacteria on the establishment of bifidobacteria colonizing the gut in infants," Pediatric Research, vol. 65, no. 6, pp. 669-674, 2009.

[57] S. Matamoros, C. Gras-Leguen, F. Le Vacon, G. Potel, and M.F. de La Cochetiere, "Development of intestinal microbiota in infants and its impact on health," Trends in Microbiology, vol. 21, no. 4, pp. 167-173, 2013.

[58] I. L. Khalif, E. M. M. Quigley, E. A. Konovitch, and I. D. Maximova, "Alterations in the colonic flora and intestinal permeability and evidence of immune activation in chronic 
constipation," Digestive and Liver Disease, vol. 37, no. 11, pp. 838849, 2005.

[59] K. Al-Nedawi, M. F. Mian, N. Hossain et al., "Gut commensal microvesicles reproduce parent bacterial signals to host immune and enteric nervous systems," FASEB Journal, vol. 29, no. 2, pp. 684-695, 2015.

[60] M. Furnari, E. Savarino, L. Bruzzone et al., "Reassessment of the role of methane production between irritable bowel syndrome and functional constipation," Journal of Gastrointestinal and Liver Diseases, vol. 21, no. 2, pp. 157-163, 2012.

[61] A. Attaluri, M. Jackson, J. Valestin, and S. S. C. Rao, "Methanogenic flora is associated with altered colonic transit but not stool characteristics in constipation without IBS," American Journal of Gastroenterology, vol. 105, no. 6, pp. 14071411, 2010.

[62] C. S. Mello, K. d. Freitas, S. Tahan, and M. B. Morais, "Consumo de fibra alimentar por crianças e adolescentes com constipação crônica: influência da mãe ou cuidadora e relação com excesso de peso," Revista Paulista de Pediatria, vol. 28, no. 2, pp. 188-193, 2010.

[63] O. B. Soylu, "Clinical findings of functional and secondary constipation in children," Iranian Journal of Pediatrics, vol. 23, no. 3, pp. 353-356, 2013.

[64] S. Aydogdu, M. Çakir, H. A. Yüksekkaya, Ç. Arikan, G. Tümgör, and M. Baran, "Chronic constipation in Turkish children: clinical findings and applicability of classification criteria," Turkish Journal of Pediatrics, vol. 51, no. 2, pp. 146-153, 2009.

[65] S. M. Borowitz, D. J. Cox, A. Tam, L. M. Ritterband, J. L. Sutphen, and J. K. Penberthy, "Precipitants of constipation during early childhood," Journal of the American Board of Family Practice, vol. 16, no. 3, pp. 213-218, 2003.

[66] J. M. Rodríguez, K. Murphy, C. Stanton et al., "The composition of the gut microbiota throughout life, with an emphasis on early life," Microbial Ecology in Health \& Disease, vol. 26, no. 1, Article ID 26050, 17 pages, 2015.

[67] E. K. Mitsou, E. Kirtzalidou, I. Oikonomou, G. Liosis, and A. Kyriacou, "Fecal microflora of Greek healthy neonates," Anaerobe, vol. 14, no. 2, pp. 94-101, 2008.

[68] R. C. Gomes, H. S. Maranhão, L. d. Pedrosa, and M. B. Morais, "Consumo de fibra alimentar e de macronutrientes por crianças com constipação crônica funcional," Arquivos de Gastroenterologia, vol. 40, no. 3, pp. 181-187, 2003.

[69] T. Hennet, A. Weiss, and L. Borsig, "Decoding breast milk oligosaccharides," Swiss Medical Weekly, vol. 144, Article ID w13927, 2014.

[70] W. Fan, G. Huo, X. Li, L. Yang, and C. Duan, "Impact of diet in shaping gut microbiota revealed by a comparative study in infants during the first six months of life," Journal of Microbiology and Biotechnology, vol. 24, no. 2, pp. 133-143, 2014.

[71] D. Garrido, S. Ruiz-Moyano, R. Jimenez-Espinoza, H.-J. Eom, D. E. Block, and D. A. Mills, "Utilization of galactooligosaccharides by Bifidobacterium longum subsp. infantis isolates," Food Microbiology, vol. 33, no. 2, pp. 262-270, 2013.

[72] L. Fernández, S. Langa, V. Martín et al., "The human milk microbiota: origin and potential roles in health and disease," Pharmacological Research, vol. 69, no. 1, pp. 1-10, 2013.

[73] E. Bezirtzoglou, V. Maipa, N. Chotoura et al., "Occurrence of Bifidobacterium in the intestine of newborns by fluorescence in situ hybridization," Comparative Immunology, Microbiology and Infectious Diseases, vol. 29, no. 5-6, pp. 345-352, 2006.
[74] F. Lara-Villoslada, S. Sierra, M. P. Díaz-Ropero, M. Olivares, and J. Xaus, "Safety assessment of the human milk-isolated probiotic Lactobacillus salivarius CECT5713," Journal of Dairy Science, vol. 90, no. 8, pp. 3583-3589, 2007.

[75] A. Donnet-Hughes, P. F. Perez, J. Doré et al., "Potential role of the intestinal microbiota of the mother in neonatal immune education," Proceedings of the Nutrition Society, vol. 69, no. 3, pp. 407-415, 2010.

[76] R. Albesharat, M. A. Ehrmann, M. Korakli, S. Yazaji, and R. F. Vogel, "Phenotypic and genotypic analyses of lactic acid bacteria in local fermented food, breast milk and faeces of mothers and their babies," Systematic and Applied Microbiology, vol. 34, no. 2, pp. 148-155, 2011.

[77] M. B. Azad, T. Konya, H. Maughan et al., "Gut microbiota of healthy Canadian infants: profiles by mode of delivery and infant diet at 4 months," Canadian Medical Association Journal, vol. 185, no. 5, pp. 385-394, 2013.

[78] H. Takahashi, K. Mikami, R. Nishino, T. Matsuoka, M. Kimura, and Y. Koga, "Comparative analysis of the properties of bifidobacterial isolates from fecal samples of mother-infant pairs," Journal of Pediatric Gastroenterology and Nutrition, vol. 51, no. 5, pp. 653-660, 2010.

[79] M. G. Dominguez-Bello, E. K. Costello, M. Contreras et al., "Delivery mode shapes the acquisition and structure of the initial microbiota across multiple body habitats in newborns," Proceedings of the National Academy of Sciences of the United States of America, vol. 107, no. 26, pp. 11971-11975, 2010.

[80] P. A. Vaishampayan, J. V. Kuehl, J. L. Froula, J. L. Morgan, H. Ochman, and M. P. Francino, "Comparative metagenomics and population dynamics of the gut microbiota in mother and infant," Genome Biology and Evolution, vol. 2, no. 1, pp. 53-66, 2010.

[81] A. Horvath, A. Chmielewska, and H. Szajewska, "Functional constipation in children: a follow-up of two randomized controlled trials," Pediatria Polska, vol. 88, no. 3, pp. 219-223, 2013.

[82] A. Khodadad and M. Sabbaghian, "Role of synbiotics in the treatment of childhood constipation: a double-blind randomized placebo controlled trial," Iranian Journal of Pediatrics, vol. 20, no. 4, pp. 387-392, 2010.

[83] P. Coccorullo, C. Strisciuglio, M. Martinelli, E. Miele, L. Greco, and A. Staiano, "Lactobacillus reuteri (DSM 17938) in infants with functional chronic constipation: a double-blind, randomized, placebo-controlled study," Journal of Pediatrics, vol. 157, no. 4, pp. 598-602, 2010.

[84] M. M. Tabbers, A. Chmielewska, M. G. Roseboom et al., "Effect of the consumption of a fermented dairy product containing Bifidobacterium lactis DN-173 010 on constipation in childhood: a multicentre randomised controlled trial," $B M C$ Pediatrics, vol. 9, no. 1, article 22, 2009.

[85] N.-L. Bekkali, M. E. J. Bongers, M. M. Van Den Berg, O. Liem, and M. A. Benninga, "The role of a probiotics mixture in the treatment of childhood constipation: A Pilot Study," Nutrition Journal, vol. 6, article 17, 2007.

[86] L.-N. Bu, M.-H. Chang, Y.-H. Ni, H.-L. Chen, and C.-C. Cheng, "Lactobacillus casei rhamnosus Lcr35 in children with chronic constipation," Pediatrics International, vol. 49, no. 4, pp. 485490, 2007.

[87] T. Nakamura, S. Nishida, M. Mizutani, and H. Iino, "Effects of yogurt supplemented and with intestinal brewer's microflora yeast on constipation in rats," Journal of Nutritional Science and Vitaminology, vol. 47, no. 6, pp. 367-372, 2001. 


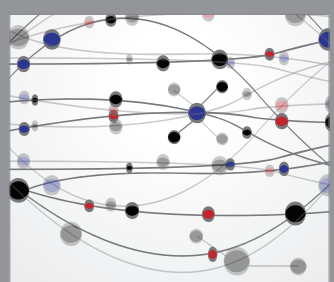

The Scientific World Journal
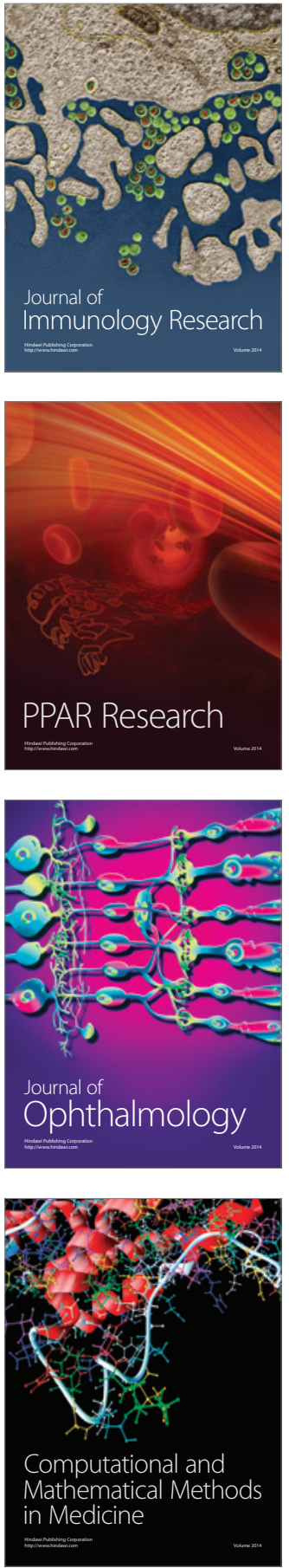

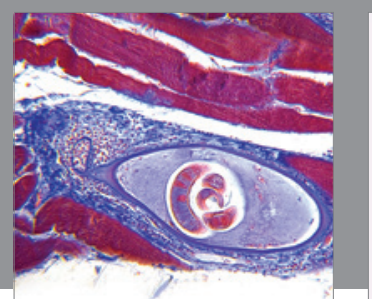

Gastroenterology Research and Practice

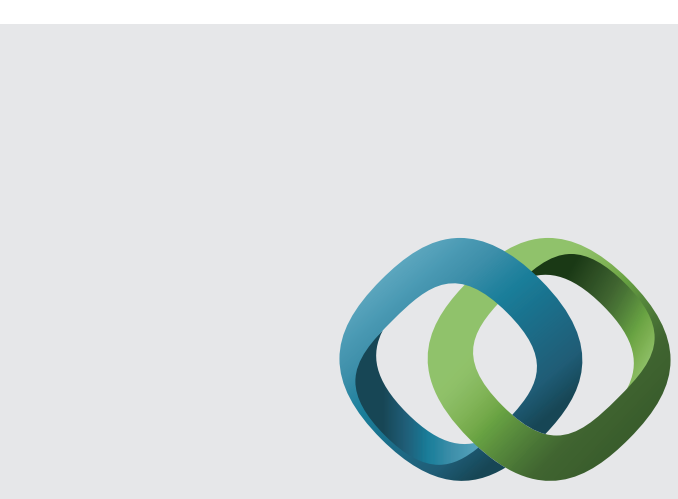

\section{Hindawi}

Submit your manuscripts at

http://www.hindawi.com
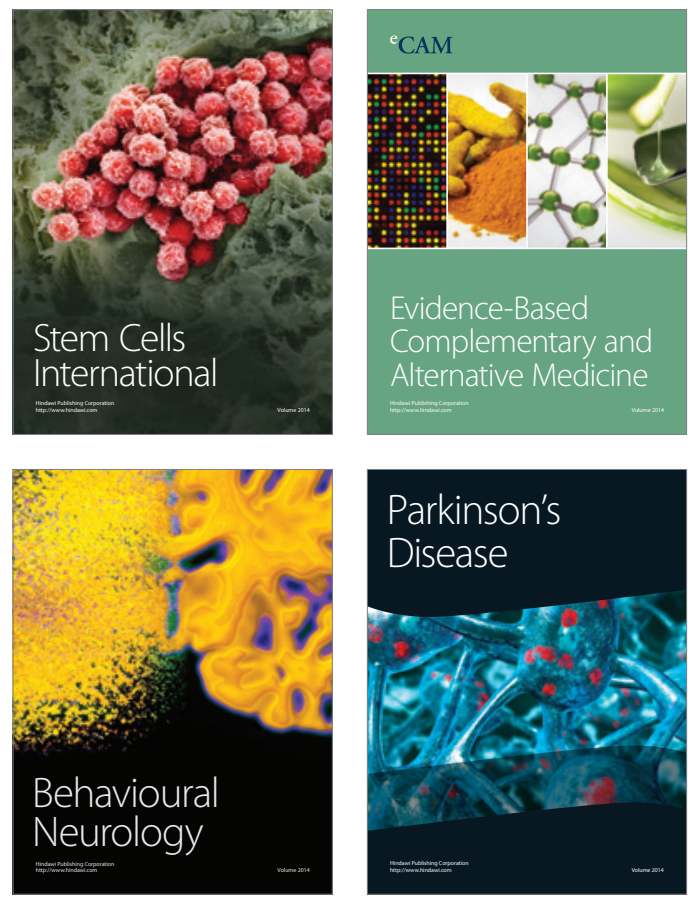
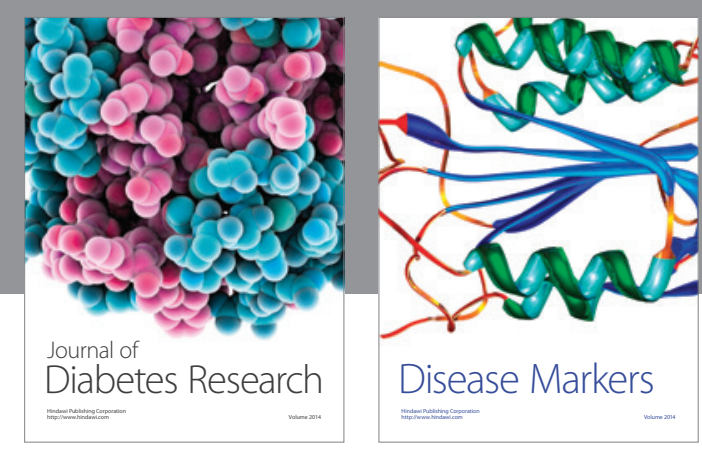

Disease Markers
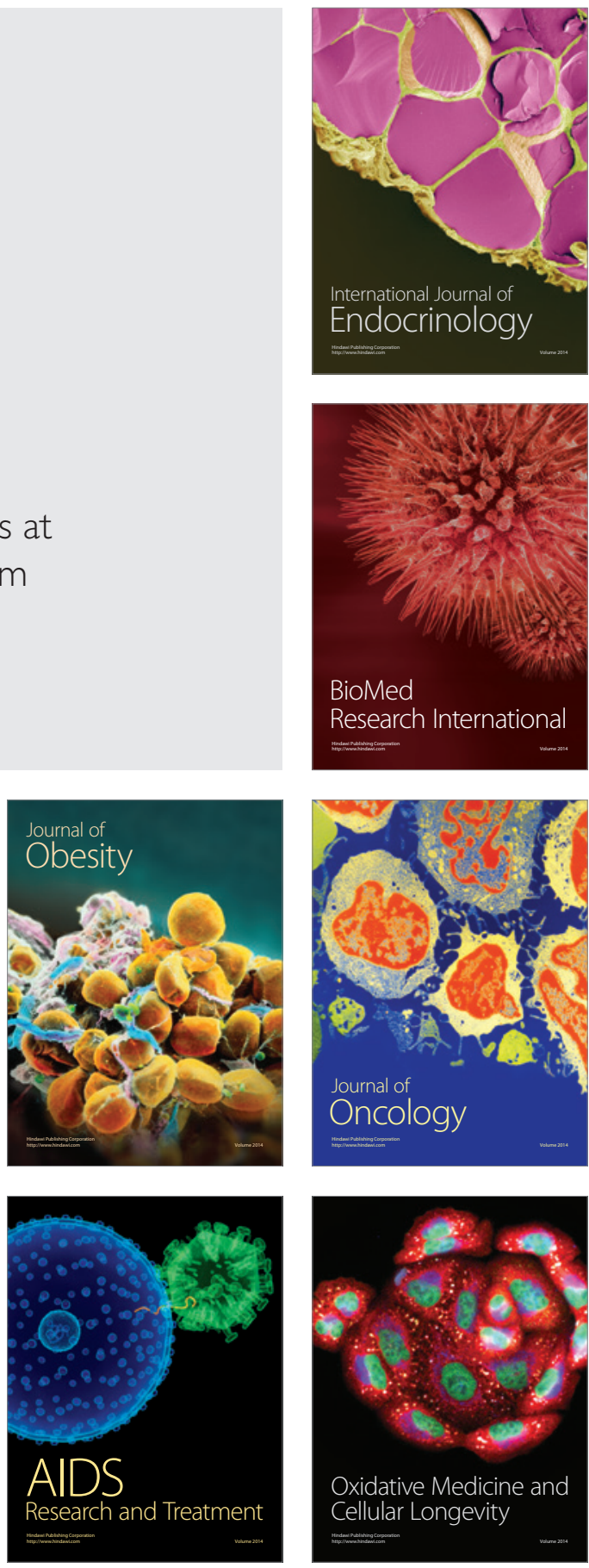